\title{
Fatty acid composition of lamb meat from Italian and German local breeds
}

\author{
Ursula Gonzales-Barron $^{\mathrm{a}, *}$, Teodora Popova ${ }^{\mathrm{b}}$, Roberto Bermúdez Piedra ${ }^{\mathrm{c}}$, Anna Tolsdorf ${ }^{\mathrm{d}}$, \\ Andreas Geß ${ }^{\mathrm{d}}$, Jaime Pires ${ }^{\mathrm{a}}$, Rubén Domínguez ${ }^{\mathrm{c}}$, Francesco Chiesa ${ }^{\mathrm{e}}$, Alberto Brugiapaglia ${ }^{\mathrm{f}}$, \\ Irene Viola ${ }^{\mathrm{e}}$, Luca M. Battaglini ${ }^{\mathrm{e}}$, Mario Baratta ${ }^{\mathrm{e}}$, José M. Lorenzo ${ }^{\mathrm{c}, \mathrm{g}}$, Vasco A.P. Cadavez ${ }^{\mathrm{a}}$ \\ ${ }^{a}$ Centro de Investigação de Montanha (CIMO), Instituto Politécnico de Bragança, 5300-253 Bragança, Portugal \\ ${ }^{\mathrm{b}}$ Agricultural Academy, Institute of Animal Science-Kostinbrod, 2232, Kostinbrod, Bulgaria \\ c Centro Tecnológico de la Carne de Galicia, Rúa Galicia No 4, Parque Tecnológico de Galicia, San Cibrao das Viñas, 32900, Ourense, Spain \\ d Department Life Cycle Engineering (GaBi), Institute for Acoustics and Building Physics (IABP), Faculty of Civil and Environmental Engineering, Stuttgart University, \\ 70563, Stuttgart, Germany \\ ${ }^{\mathrm{e}}$ Department of Veterinary Science (DSV), Università degli Studi di Torino, Turin, Italy \\ ${ }^{\mathrm{f}}$ Department of Agricultural, Forest and Food Sciences (DISAFA), Università degli Studi di Torino, Turin, Italy \\ ${ }^{g}$ Área de Tecnología de los Alimentos, Facultad de Ciencias de Ourense, Universidad de Vigo, 32004, Ourense, Spain
}

\section{A R T I C L E I N F O}

\section{Keywords:}

Sheep

Meat

Quality characteristics

Fatty acid profile

\begin{abstract}
A B S T R A C T
The aim of this study was to evaluate and compare the quality characteristics, chemical composition and lipid profile of lamb meat from Italian (Biellese and Sambucana) and German (Texel-Merino-Blackhead-Charollais [TMBC]) breeds reared in extensive and semi-extensive production systems. Meat samples from 89 animals were analysed. The meat of the lambs from semi-intensively reared Biellese, and extensively reared Sambucana and TMBC breeds produced lean meat, with slightly higher intramuscular fat content in TMBC. The latter also produced meat of darker colour $(\mathrm{P}<0.05)$ and higher protein content $(\mathrm{P}<0.05)$. The meat of Sambucana lambs presented the lowest total cholesterol content $(\mathrm{P}<0.05)$. The fatty acid profile of the meat showed a clear advantage of both extensively reared breeds, which had substantially lower proportion of saturated but higher of polyunsaturated fatty acids, particularly n-3 $(\mathrm{P}<0.05)$. The beneficial effect of the extensive rearing conditions was associated with lower $n-6 / n 3$ ratio, and atherogenic and thrombogenic indices, thereby suggesting that production system can be used successfully to modify the fatty acid profile to achieve a positive effect for the human health.
\end{abstract}

\section{Introduction}

A renewed interest in local sheep breeds has been prompted by the EU's recent promotion of a sustainable development of otherwise marginal areas and policies supporting extensive systems of animal production (Marino et al., 2008). Local sheep production is more likely to be found in low farming areas, where sheep graze semi-natural vegetation and are dominant with other low input extensive grazing livestock (Cruz et al., 2019). Even though sheep farming represents only a small contribution to Europe's gross domestic product $(<0.5 \%$; (Eurostat, 2019)), the sector is of great importance to rural development and the environment. The indigenous sheep breeds, in addition to contributing to the diversity of production systems, are important genetic resources that must be preserved because of their local adaptation, disease resistance, high fertility and unique product qualities (Mendelsohn, 2003).
Some of these breeds have small body and good adaptation to adverse climatic and orographic environments, which makes them particularly suited to the use and enhancement of natural pastures (Cruz et al., 2019).

One strategy for attaining sustainability of the local sheep farming sector is through high quality standard of the products. Enhancing the quality of meat from autochthonous breeds, making it more attractive to consumers, could contribute to the preservation of the rural world and its diversity, the conservation of endangered breeds, as well as improving the profitability and living standards of the sheep farmers that remain in these rural areas. Nonetheless, meat quality is a very ample concept defined by industry and the final consumer, which is regulated by a series of factors that are intrinsic and extrinsic to the animal (Webb et al., 2005). Fatty acid composition alone has a strong impact on the nutritive value and the organoleptic characteristics of

\footnotetext{
* Corresponding author.

E-mail address: ubarron@ipb.pt (U. Gonzales-Barron).
} 
meat (Díaz et al., 2005). The flavour profile, an important attribute of meat, is regulated by variations in the absolute concentration and the relative proportions of different fatty acids (Fisher et al., 2000). Several studies have confirmed that meat fatty acid composition can be influenced by production system, animal breed and sex, slaughter age and live weight, and level of fatness (Atti and Mahouachi, 2009; Boughalmi and Araba, 2016; Domínguez et al., 2015, 2018b; Ekiz et al., 2013).

Therefore, the objective of this study was to evaluate and compare the physicochemical attributes (ultimate $\mathrm{pH}$, colour, proximate composition and cholesterol content) and fatty acid profile of lamb meat originating from three Italian and German breeds typically raised in extensive or semi-extensive production systems. Three sheep breeds exploited for meat production, in their typical production systems, were utilised in the present study: Sambucana lambs raised in extensive system and Biellese lambs raised in semi-extensive system from the Alpine and the Continental bioregions of Italy, respectively, and crossbred Texel-Merino-Blackhead-Charollais (TMBC) lambs reared in extensive system from the Continental bioregion of Germany.

\section{Methodology}

\subsection{Lamb rearing and feeding}

All animals' management and procedures were carried out in accordance with EU Directive 2010/63/EU for animal experiments.

\subsubsection{Italy}

In the Continental bioregion, located in Turin, Biellese lambs were raised in CISRA, Teaching Animal Farm of the Veterinary Science Department, University of Turin. In the Alpine bioregion, located in Val Maira, Western Alps, at an altitude of 1800-2000 m, Sambucana lambs were bred during the summer season. The lambs from both breeds were raised in collective pens with their mothers. The production system used for Biellese breed was semi-extensive (i.e., the lambs consumed about $500 \mathrm{~g}$ of milk per day the first 15 days after birth and then $1000 \mathrm{~g}$ per days until weaning ( 2 months of age)). After weaning, the lambs were fed with $\sim 200 \mathrm{~g}$ of concentrate per day and $700 \mathrm{~g}$ of hay until the slaughtering (4.5-5 months of age). The production system for Sambucana lambs was based on grazing on natural pasture, with no additional concentrate or hay. The lambs were fed $400 \mathrm{~g}$ of milk per day the first 15 days after birth and until 2 month of age the animals received $800 \mathrm{~g}$ of milk per day. In the semi-extensive system for Biellese lambs, the flocks would be released to graze outside in autumn-winter season (period of investigation); whereas in the extensive system, Sambucana lambs would leave at dawn and graze until evening; then they would be recovered in a fence in summer season (period of investigation). The lambs were not weaned during the grazing season in the Alpine bioregion. For this investigation, 16 Biellese and 20 Sambucana lambs were reared in 2018, and 12 Biellese and 12 Sambucana lambs were reared in 2019.

\subsubsection{Germany}

The lambs, all crossbred Texel-Merino-Blackhead-Charollais (TMBC), were raised in a farm at an abandoned military training area on the Swabian Alb near Münsingen; and held in one collective flock. The animals stayed in a pen overnight and during the day they roam freely. The study area belongs to bio-region Kuppenalb, located in the eco-region called the "Western European Broadleaf Forests". The study pasture of 170 ha is managed extensively, and grazed by a mid-sized flock of around 500 ewes. The insemination is carried out naturally in spring. During winter, traditional transhumance is practiced to the lower Swabian areas of Nördlingen. The animals graze all year long, and the only additionally provided fodder is mineral feed. On this farm 29 lambs were reared.

\subsection{Preparation of lamb meat samples}

All lambs were four-to-five months old when slaughtered. Lambs were slaughtered in batches ranging from 5 to 12 animals in local abattoirs of Italy and Germany, and the whole experiment was conducted in the fall and spring seasons of 2018 and 2019. A total of 89 lambs were employed in this study, from the following breeds and production systems: Biellese semi-extensive (28), Sambucana extensive (32), TMBC extensive (29).

Lambs were slaughtered after an overnight lairage period, where they had free access to water but not to feed. In the local abattoirs, lambs were electrically stunned, dressed, washed and chilled at $4{ }^{\circ} \mathrm{C}$. Twentyfour hours after slaughter, carcasses were split and the Longissimus thoracis et lumborum muscles removed from the 6th to the 13th vertebra under aseptic conditions. The right side was divided into two parts for subsequent laboratorial analysis. They were vacuum packed in transparent gas-tight polyamide and polyethylene vacuum bags (Orved ${ }^{\circledR}$, Spain, with permeability of $84 \pm 4.20 \mathrm{cc} / \mathrm{m}^{2} / 24 \mathrm{~h} / \mathrm{atm}$ for $\mathrm{O}_{2}$, $361 \pm 18.05 \mathrm{cc} / \mathrm{m}^{2} / 24 \mathrm{~h} / \mathrm{atm}$ for $\mathrm{CO}_{2}, 22 \pm 1.10 \mathrm{cc} / \mathrm{m}^{2} / 24 \mathrm{~h} / \mathrm{atm}$ for $\mathrm{N}_{2}$ and $9.0 \pm 0.45 \mathrm{cc} / \mathrm{m}^{2} / 24 \mathrm{~h} / \mathrm{atm}$ for $\mathrm{H}_{2} \mathrm{O}$ and density of $\pm 100 \mu \mathrm{m}$ ), and stored at $4 \pm 0.5{ }^{\circ} \mathrm{C}$. Within $24 \mathrm{~h}$, the meat samples were subjected to the following determinations: $\mathrm{pH}$ and instrumental colour measurement, proximate composition, cholesterol content and fatty acid profile. All the essays were carried out in the same laboratory.

\subsection{Physicochemical analyses of meat}

\subsection{1. $p H$ and instrumental colour measurements}

The $\mathrm{pH}$ was measured in triplicate using a digital portable $\mathrm{pH}$-meter (Hanna Instruments, Eibar, Spain) equipped with a penetration glass probe. A portable colorimeter (Konica Minolta CR-600d, Osaka, Japan) was used to measure in triplicate the meat colour in the CIELAB space (lightness $\mathrm{L}^{*}$, redness $\mathrm{a}^{*}$ and yellowness $\mathrm{b}^{*}$ ). The device was set to pulsed xenon arc lamp, $10^{\circ}$ viewing angle geometry, standard illuminant D65 and aperture size of $8 \mathrm{~mm}$. Samples were allowed to bloom for $30 \mathrm{~min}$ before measuring.

\subsubsection{Proximate composition}

Moisture, intramuscular fat, protein and ashes contents were determined according to ISO (1997); AOCS (2005); ISO (1978) and ISO (1998), respectively. Determinations were made in triplicate per meat sample.

\subsubsection{Cholesterol analysis}

Total cholesterol was analysed (saponification, separation and quantification) following the procedure described by Domínguez et al. (2018a). Two grams of homogenised meat sample were placed in a screw Teflon-lined cap tube and $0.25 \mathrm{~g}$ of $\mathrm{L}$-ascorbic acid and $5 \mathrm{~mL}$ of saponification solution [11 \% potassium hydroxide in ethanol solution (55\%)] were added. The saponification step was carried out in a shaking water bath at $85^{\circ} \mathrm{C}$ for $45 \mathrm{~min}$. After cooling, cholesterol was extracted with $1.5 \mathrm{~mL}$ of hexane. Cholesterol was separated and quantified using normal phase-HPLC technique, according the chromatographic conditions reported by Domínguez et al. (2018a). The HPLC systems used was an Alliance 2695 model (Waters, Milford, USA) equipped with a 996 Photodiode Array Detector (Waters Milford, USA). The cholesterol analysis was performed using a normal-phase silica column (SunFireTM Prep Silica, $4.6 \mathrm{~mm}$ ID $\times 250 \mathrm{~mm}, 5 \mu \mathrm{m}$ particle size, Waters, Milford, MA, USA). The mobile phase ( $2 \% \mathrm{v} / \mathrm{v} 2$-propanol in $\mathrm{n}$-hexane) flow rate was $1 \mathrm{~mL} / \mathrm{min}$, the run last for $15 \mathrm{~min}$ and the temperature of the column oven was adjusted at $30^{\circ} \mathrm{C}$. The detection of cholesterol was carried out using Photodiode Array detector at $208 \mathrm{~nm}$. Results were expressed as $\mathrm{mg}$ of cholesterol/100 $\mathrm{g}$ of meat. 


\subsection{Fatty acid composition analysis}

Intramuscular lipids were extracted following the method described by Bligh and Dyer (1959) with the modifications proposed by Barros et al. (2020). The procedure described by Barros et al. (2020) was used for fatty acids determination. Briefly, $20 \mathrm{mg}$ of extracted fat were trans-esterified with sodium methoxide $(0.5 \mathrm{~N})$ and $\mathrm{H}_{2} \mathrm{SO}_{4}$ solution (10 $\%$ of $\mathrm{H}_{2} \mathrm{SO}_{4}$ in methanol). Then, the fatty acid methyl esters (FAMEs) were extracted with hexane and transferred to a gas chromatography vial. Separation and quantification of FAMEs were carried out using a gas chromatograph (GC-Agilent 7890B, Agilent Technologies, Santa Clara, CA, USA) equipped with a flame ionization detector (FID) and PAL RTC-120 auto sampler. One microliter of sample was injected in split mode (1:50). For the separation of FAMEs, a DB-23 fused silica capillary column $(60 \mathrm{~m}, 0.25 \mathrm{~mm}$ i.d., $0.25 \mu \mathrm{m}$ film thickness; Agilent Technologies) was used. Chromatographic conditions were as follows: initial oven temperature of $50{ }^{\circ} \mathrm{C}$ (held for $1 \mathrm{~min}$ ), first ramp at $25^{\circ} \mathrm{C} / \mathrm{min}$ to $175^{\circ} \mathrm{C}$, second ramp at $4{ }^{\circ} \mathrm{C} / \mathrm{min}$ to $230^{\circ} \mathrm{C}$ (held for $5 \mathrm{~min}$ ) and third ramp at $4{ }^{\circ} \mathrm{C} / \mathrm{min}$ to a final temperature of $240{ }^{\circ} \mathrm{C}$ (held for $2.75 \mathrm{~min}$ ). Helium was used as a carrier gas at a constant flow-rate of $1.2 \mathrm{~mL} / \mathrm{min}$. The FID detector was maintained at $280{ }^{\circ} \mathrm{C}$, while the operational flows were set as $40 \mathrm{~mL} / \mathrm{min}$ of $\mathrm{H}_{2}, 450 \mathrm{~mL} / \mathrm{min}$ of air and $30 \mathrm{~mL} / \mathrm{min}$ of makeup flow. Individual FAMEs were identified by comparing their retention times with those of authenticated standards and the results were expressed as $\%$ of total FAME.

The total contents of saturated fatty acids (SFAs), monounsaturated fatty acids (MUFAs), polyunsaturated fatty acids (PUFAs), PUFA n- 6 and PUFA n-3 were calculated. The PUFA n-6/n-3 ratios were also calculated. The atherogenic (AI) and thrombogenic (TI) indices, as proposed by Ulbricht and Southgate (1991), were calculated according to the following equations:

$$
\begin{aligned}
& \mathrm{AI}=(\mathrm{C} 12: 0+4 \times \mathrm{C} 14: 0+\mathrm{C} 16: 0) /[\mathrm{MUFA}+\Sigma(\mathrm{n}-6)+\Sigma(\mathrm{n}-3)] \\
& \mathrm{TI}=(\mathrm{C} 14: 0+\mathrm{C} 16: 0+\mathrm{C} 18: 0) /[0.5 \times \operatorname{MUFA}+0.5 \times(\mathrm{n}-6)+3 \times(\mathrm{n}-3)+(\mathrm{n}-3 / \mathrm{n}-6)]
\end{aligned}
$$

\subsection{Statistical analysis}

Each physicochemical attribute and fatty acid component of meat was subjected to one-way analysis of variance (ANOVA). Differences between the least square means of the quality attributes in the three breeds were compared by the Tukey's Honest Significant Difference test $(\alpha=0.05)$.

\section{Results and discussion}

\subsection{Ultimate $\mathrm{pH}$ and colour}

The $\mathrm{pH}$ values measured $24 \mathrm{~h}$ post mortem differed significantly between the three examined breeds $(\mathrm{P}<0.001)$ as presented in Table 1 . The lowest $\mathrm{pH}$ was observed in the muscle of the German TMBC lambs (5.56), while the two Italian breeds showed higher values of this parameter (5.62 and 5.69, respectively for the Biellese and Sambucana).

Table 1

Ultimate $\mathrm{pH}$ and instrumental colour measurements of m. Longissimus thoracis et lumborum in lambs from Biellese, Sambucana and Texel-Merino-BlackheadCharollais (TMBC) breeds.

\begin{tabular}{llllll}
\hline Attribute $^{1}$ & Biellese & Sambucana & TMBC & SEM $^{2}$ & P-value \\
\hline $\mathrm{pH}_{24}$ & $5.62^{\mathrm{a}}$ & $5.69^{\mathrm{b}}$ & $5.56^{\mathrm{c}}$ & 0.06 & $<0.0001$ \\
$\mathrm{~L}^{*}$ & $45.95^{\mathrm{a}}$ & $45.47^{\mathrm{a}}$ & $40.63^{\mathrm{b}}$ & 2.83 & $<0.0001$ \\
$\mathrm{a}^{*}$ & $9.91^{\mathrm{a}}$ & $10.32^{\mathrm{a}}$ & $12.31^{\mathrm{b}}$ & 1.72 & $<0.0001$ \\
$\mathrm{~b}^{*}$ & 12.56 & 12.57 & 12.49 & 1.38 & 0.972 \\
\hline
\end{tabular}

${ }^{1}$ Values with different superscript letters differ significantly, $\mathrm{P}<0.05$.

${ }^{2}$ Standard error of the means.
Apart from the ante-mortem stress, it is suggested that the production system of the animals can affect the ultimate $\mathrm{pH}$ of the meat. The extensively reared animals have relatively small but sufficient glycogen reserves to ensure a gradual post mortem decline of the $\mathrm{pH}$ in muscle producing meat with a slightly though not significantly higher $\mathrm{pH}$ compared to intensively reared animals (Priolo et al., 2001). This partially agrees with the results observed in Sambucana breed reared under extensive system but also in the semi-intensively reared Biellese. On the other hand, the extensively reared TMBC lambs produced meat with considerably lower $\mathrm{pH}$ when compared to the other two breeds. In contrast, other authors conclude that the rearing system (semi-extensive system vs. extensive system) did not influence $\mathrm{pH}$ values of foal meat (Franco et al., 2011).

Ultimate $\mathrm{pH}$ is used to assess the shelf life and quality of meat as well as its suitability for processing. The normal $\mathrm{pH}$ decline is from 7.0 to 7.2 to 5.5-5.7 over about $24 \mathrm{~h}$ (Boles and Pegg, 1999). According to Mullen and Troy (2005), the meat with an ultimate $\mathrm{pH}$ around 5.5-5.7 possesses the most desirable fresh quality characteristics. Earlier, Devine et al. (1993) reported that young lambs with ultimate $\mathrm{pH}$ lower than 5.7 gave the crossbred TMBC most tender meat. The values of ultimate $\mathrm{pH}$ measured in this study fall within the recommended range for high quality of the meat.

Meat colour is one of most important characteristics used by the consumers as a visual quality indicator for freshness of meat. Significant difference in the lightness $\left(\mathrm{L}^{*}\right)$ and redness $\left(\mathrm{a}^{*}\right)$ of the meat among the three breeds was observed in this study $(\mathrm{P}<0.0001)$. Regardless of the rearing system, both breeds from Italy showed similar $L^{*}$ values (45.95 and 45.75, for the Biellese and Sambucana respectively); however, the TMBC lambs had significantly darker meat $\left(L^{*}=40.63\right)$, corresponding with the highest $\mathrm{a}^{*}$ value observed in this breed (12.31 vs. 9.91 and 10.31 for the Biellese and Sambucana). The colour parameters of the meat in the examined breeds are similar to the reported by other authors in lamb meat (Luciano et al., 2012; Teixeira et al., 2005; Tejeda et al., 2008). However, in Sambucana lambs, Battaglini et al. (2004) observed considerably lower L* (36.27) and higher a* (14.47).

\subsection{Proximate composition and cholesterol content}

With exception of the IMF content, all the chemical components of the meat differed significantly between the two indigenous Italian breeds and the TMBC lambs, as presented in Table $2(\mathrm{P}<0.0001)$. The meat of Biellese and Sambucana lambs had low fat content $(1.40 \%-1.60$ $\%$ ), which did not differ one from another despite the different production systems. Similar low IMF contents of $\mathrm{m}$. L. thoracis et lumborum in these breeds were previously reported by Battaglini et al. (2004) and Brugiapaglia et al. (2019). The IMF in the muscles of TMBC lambs tended to be higher $(P=0.087$ at $\alpha=0.10$ ) than both indigenous breeds. Italian breeds showed similar content of protein (19.60\%-19.64\%), ashes (1.06 \%-1.08\%) and moisture (77.15 \%-77.30\%). When compared to them, the meat from TMBC lambs presented significantly higher protein content $(21.38 \%)$ corresponding to the higher ashes (1.22 \%), but lower moisture (75.43\%). The advantage of the meat from TMBC lambs regarding the chemical composition and in particular

Table 2

Proximate composition (\%) and cholesterol content (mg/100 g meat) of m. Longissimus thoracis et lumborum in lambs from Biellese, Sambucana and TexelMerino-Blackhead-Charollais (TMBC) breeds.

\begin{tabular}{llllll}
\hline Attribute $^{1}$ & Biellese & Sambucana & TMBC & SEM $^{2}$ & P-value \\
\hline IMF & 1.60 & 1.40 & 1.84 & 0.76 & 0.087 \\
Protein & $19.64^{\mathrm{a}}$ & $19.60^{\mathrm{a}}$ & $21.38^{\mathrm{b}}$ & 0.57 & $<0.0001$ \\
Moisture & $77.30^{\mathrm{a}}$ & $77.15^{\mathrm{a}}$ & $75.43^{\mathrm{b}}$ & 0.95 & $<0.0001$ \\
Ash & $1.06^{\mathrm{a}}$ & $1.08^{\mathrm{a}}$ & $1.22^{\mathrm{b}}$ & 0.06 & $<0.0001$ \\
Cholesterol & $51.73^{\mathrm{a}}$ & $28.53^{\mathrm{b}}$ & $53.38^{\mathrm{a}}$ & 22.54 & $<0.0001$ \\
\hline 1
\end{tabular}

${ }^{1}$ Values with different superscript letters differ significantly, $\mathrm{P}<0.05$.

2 Standard error of the means. 
protein content over the Italian autochthonous breeds might be due to their crossbreed origin, and especially the presence of Texel and Charollais breeds. When comparing indigenous Segurena breed with its Texel crossbreed, Blasco et al. (2019) observed higher protein content in the meat of the crossbreed lambs.

The cholesterol content of meat was significantly different among the breeds $(\mathrm{P}<0.0001)$ and varied between $28.53 \mathrm{mg} / 100 \mathrm{~g}$ and $53.38 \mathrm{mg}$ / $100 \mathrm{~g}$. The lowest value was measured in the muscles of Sambucana lambs. Data from several studies suggested that breed is the most important factor affecting the cholesterol content in lamb carcass. However, Salvatori et al. (2004) demonstrated clear differences in the cholesterol levels among three muscles in extensively reared crossbred lambs, with values determined in $\mathrm{m}$. LD within the range of $56.5-63.0 \mathrm{mg} / 100 \mathrm{~g}$. Furthermore, in indigenous breeds and crosses, Costa et al. (2009) observed 65.88-67.88 mg/100 g, with no effect of the energy levels of the feed. These values are slightly higher from the ones in this study, and particularly in comparison with the cholesterol levels in the meat of Sambucana lambs. The latter was similar to the one reported by Serra et al. (2014), in Massese sucking lambs slaughtered at $11-17 \mathrm{~kg}$.

\subsection{Fatty acid composition}

The fatty acid profile presented in Table 3 revealed substantial differences among the breeds. In comparison to the two breeds reared under extensive systems, the meat of semi-intensive Biellese lambs is characterised by higher saturation of the fatty acid profile. This was associated with increased percentage of C16:0 (25.21\%) and C18:0 $(18.57 \%)$, which are the major saturated fatty acids in the muscle tissue. The proportion of these two fatty acids also differed significantly between the two breeds reared in extensive system. The meat of

Table 3

Fatty acid composition (\% FAME) of $\mathrm{m}$. Longissimus thoracis et lumborum in lambs from Biellese, Sambucana and Texel-Merino-Blackhead-Charollais (TMBC) breeds. Only the fatty acids that represented more than $0.1 \%$ are presented.

\begin{tabular}{|c|c|c|c|c|c|}
\hline Fatty acid ${ }^{1}$ & Biellese & Sambucana & TMBC & SEM $^{2}$ & P-value \\
\hline C10:0 & $0.23^{\mathrm{a}}$ & $0.16^{\mathrm{b}}$ & $0.20^{\mathrm{ab}}$ & 0.07 & 0.0046 \\
\hline C12:0 & $0.55^{\mathrm{a}}$ & $0.41^{\mathrm{b}}$ & $0.46^{\mathrm{ab}}$ & 0.19 & 0.0390 \\
\hline C14:0 & 4.49 & 3.99 & 4.64 & 1.20 & 0.086 \\
\hline C14:1n-5 & 0.14 & 0.12 & 0.14 & 0.07 & 0.2812 \\
\hline C15:0 & $0.58^{\mathrm{a}}$ & $0.66^{\mathrm{b}}$ & $0.58^{\mathrm{a}}$ & 0.12 & 0.0070 \\
\hline C15:1n-5 & $<0.001^{\mathrm{a}}$ & $0.63^{\mathrm{b}}$ & $0.87^{\mathrm{b}}$ & 0.78 & 0.0002 \\
\hline C16:0 & $25.21^{\mathrm{a}}$ & $21.38^{\mathrm{b}}$ & $22.79^{c}$ & 2.16 & 0.0013 \\
\hline C16:1n-7 & $1.43^{\mathrm{a}}$ & $1.18^{\mathrm{b}}$ & $1.26^{\mathrm{a}}$ & 0.25 & $<0.0001$ \\
\hline C17:0 & $1.26^{\mathrm{a}}$ & $1.20^{\mathrm{a}}$ & $1.04^{\mathrm{b}}$ & 0.13 & $<0.0001$ \\
\hline C17:1n-7 & $0.37^{\mathrm{a}}$ & $0.19^{\mathrm{b}}$ & $0.49^{\mathrm{a}}$ & 0.23 & $<0.0001$ \\
\hline C18:0 & $18.57^{\mathrm{a}}$ & $17.12^{\mathrm{b}}$ & $15.37^{c}$ & 2.19 & $<0.0001$ \\
\hline 9t-C18:1 & $0.45^{\mathrm{a}}$ & $0.55^{\mathrm{a}}$ & $0.76^{\mathrm{b}}$ & 0.23 & $<0.0001$ \\
\hline $11 \mathrm{t}-\mathrm{C} 18: 1$ & $2.31^{\mathrm{a}}$ & $3.41^{\mathrm{b}}$ & $2.48^{\mathrm{a}}$ & 0.85 & $<0.0001$ \\
\hline C18:1n-9 & $31.24^{\mathrm{a}}$ & $26.91^{b}$ & $30.86^{\mathrm{a}}$ & 2.68 & $<0.0001$ \\
\hline C18:1n-7 & 0.86 & 0.91 & 0.89 & 0.16 & 0.5403 \\
\hline $9 t, 11 \mathrm{t}-\mathrm{C} 18: 2$ & $0.23^{\mathrm{a}}$ & $0.51^{b}$ & $0.24^{\mathrm{a}}$ & 0.11 & $<0.0001$ \\
\hline$C 18: 2 n-6$ & $5.88^{\mathrm{a}}$ & $7.61^{b}$ & $6.53^{\mathrm{ab}}$ & 1.99 & 0.0043 \\
\hline $\mathrm{C} 20: 0$ & $0.15^{\mathrm{a}}$ & $0.20^{\mathrm{b}}$ & $0.12^{\mathrm{c}}$ & 0.03 & $<0.0001$ \\
\hline C20:1n-9 & $0.10^{\mathrm{a}}$ & $0.15^{\mathrm{b}}$ & $0.09^{\mathrm{b}}$ & 0.04 & $<0.0001$ \\
\hline$C 18: 3 n-3$ & $1.09^{\mathrm{a}}$ & $3.00^{\mathrm{b}}$ & $2.50^{\mathrm{c}}$ & 0.59 & $<0.0001$ \\
\hline 9c, 11t-C18:2 (CLA) & $0.69^{\mathrm{a}}$ & $1.48^{\mathrm{b}}$ & $1.67^{\mathrm{c}}$ & 0.28 & $<0.0001$ \\
\hline$C 20: 2 n-6$ & $0.05^{\mathrm{a}}$ & $0.15^{\mathrm{b}}$ & $0.15^{\mathrm{b}}$ & 0.11 & 0.0007 \\
\hline C22:0 & $0.25^{\mathrm{ab}}$ & $0.32^{\mathrm{a}}$ & $0.18^{\mathrm{b}}$ & 0.17 & 0.0075 \\
\hline$C 20: 3 n-6$ & $0.17^{\mathrm{a}}$ & $0.29^{\mathrm{b}}$ & $0.23^{\mathrm{ab}}$ & 0.10 & 0.0001 \\
\hline$C 20: 3 n-3$ & $0.02^{\mathrm{a}}$ & $0.06^{\mathrm{b}}$ & $0.20^{c}$ & 0.04 & $<0.0001$ \\
\hline$C 20: 4 n-6$ & $2.01^{\mathrm{a}}$ & $3.09^{\mathrm{b}}$ & $2.25^{\mathrm{a}}$ & 1.28 & 0.0037 \\
\hline $\mathrm{C} 24: 0$ & $0.01^{\mathrm{a}}$ & $0.05^{\mathrm{b}}$ & $0.01^{\mathrm{a}}$ & 0.03 & $<0.0001$ \\
\hline C20:5n-3 & $0.41^{\mathrm{a}}$ & $1.73^{\mathrm{b}}$ & $1.12^{\mathrm{c}}$ & 0.64 & $<0.0001$ \\
\hline C22:5n-6 & 0.10 & 0.14 & 0.11 & 0.11 & 0.7269 \\
\hline C22:5n-3 & $0.65^{\mathrm{a}}$ & $1.78^{\mathrm{b}}$ & $1.22^{\mathrm{c}}$ & 0.58 & $<0.0001$ \\
\hline C22:6n-3 & $0.34^{\mathrm{a}}$ & $0.49^{\mathrm{b}}$ & $0.44^{\mathrm{ab}}$ & 0.18 & 0.0058 \\
\hline
\end{tabular}

\footnotetext{
${ }^{1}$ Values with different superscript letters differ significantly, $\mathrm{P}<0.05$
}

2 Standard error of the means.
Sambucana lambs had a lower percentage of C16:0 than TMBC $(21.38 \%$ vs. $22.79 \%$ ), however the opposite was observed for the content of C18:0 (17.12 \% vs. $15.37 \%)$. The other saturated fatty acid present in considerable proportions in the muscle tissue (C14:0) tended to differ among the breeds $(\mathrm{P}=0.086)$, and showed lower amounts in the meat from Sambucana lambs, when compared with the other two breeds (3.99 $\%$ vs. $4.49 \%$ and $4.64 \%$, respectively for the Biellese and TMBC). Lauric acid (C12:0) also differed among breeds $(P=0.039)$, with the lowest percent observed in Sambucana lamb meat, and the highest values for the Biellese lamb meat $(\mathrm{P}<0.05)$. The TMBC lamb meat remained in intermediate position with regards to the content of C12:0. Our results contradict the observations of Pompa-Roborzyński and Kędzior (2006) who showed increased proportion of saturated fatty acids, and in particular C18:0 and C14:0 in lambs reared under extensive system. However, Lorenzo et al. (2010) reported similar results to those observed in the present study. Lambs reared in extensive system had lower SFA content $(\mathrm{P}>0.05)$ in comparison with those reared in semi-extensive system, mainly due to significantly lower C16:0 values in the animals reared under extensive production system. Significant differences among breeds were also observed in regard to other fatty acids that are present in relatively low proportions, but with no consistent trends (Table 3). The percentage of C15:0 was higher in Sambucana lamb meat $(0.66 \%)$ in comparison to the other two breeds $(0.58 \%)$, while the content of C17:0 was lower in TMBC (1.04 \% vs $1.20-1.26 \%)$.

Substantial differences $(\mathrm{P}<0.0001)$ among breeds existed with regards to monounsaturated fatty acids (MUFA) (Table 4). The lowest proportion was observed in the meat of Sambucana lambs (34.10\%) in comparison to Biellese (36.97\%) and TMBC (37.89\%), which could be explained with the significantly lower percentage of C18:1n-9 in this breed $(26.91 \%$ vs. $34.24 \%$ and $30.86 \%$, for the Biellese and TMBC, respectively). Meat of Sambucana animals also presented the lowest percent of C16:1n-7 compared to the other breeds. On the other hand, despite the lower proportions of C18:1n-9 and C16:1n-7, the muscles of Sambucana presented a significantly higher proportion of trans-vaccenic acid (11t-C18:1) than Biellese and TMBC $(\mathrm{P}<0.05)$, corresponding to the high content of conjugated linoleic acid (9c,11t-C18:2; CLA) observed in this breed. Trans-vaccenic acid as well as CLA are intermediate compounds in the biohydrogenation process of C18:2n- 6 and its conversion to C18:0 (Song and Kennelly, 2003). CLA are found in increased amounts in the ruminants reared on pasture, which is confirmed also in this study with significantly higher proportion of CLA in both extensively reared breeds $(1.48 \%-1.67 \%)$, in comparison to Biellese.

It should be noted, however, that the proportion of trans-vaccenic acid is only significantly higher in Sambucana and not in TMBC when compared to the semi-intensive Belliese. Furthermore, the TMBC lamb meat showed significantly lower percentage of trans-vaccenic acid than Sambucana. It could be suggested that the conversion of CLA to trans-

Table 4

Total proportions of saturated fatty acids (SFA), monounsaturated fatty acids (MUFA), polyunsaturated fatty acids (PUFA), PUFA n-3, PUFA n-6, PUFA n- $6 / \mathrm{n}$ 3 ratios, and atherogenic (AI) and thrombogenic (TI) indices in lamb meat from Biellese, Sambucana and Texel-Merino-Blackhead-Charollais (TMBC) breeds.

\begin{tabular}{llllll}
\hline Attribute $^{1}$ & Biellese & Sambucana & TMBC & SEM $^{2}$ & P-value \\
\hline SFA (\%) & $51.33^{\mathrm{a}}$ & $45.54^{\mathrm{b}}$ & $45.43^{\mathrm{b}}$ & 3.30 & $<0.0001$ \\
MUFA (\%) & $36.97^{\mathrm{a}}$ & $34.07^{\mathrm{b}}$ & $37.85^{\mathrm{a}}$ & 3.07 & $<0.0001$ \\
PUFA (\%) & $11.70^{\mathrm{a}}$ & $20.39^{\mathrm{b}}$ & $16.72^{\mathrm{c}}$ & 4.81 & $<0.0001$ \\
n-3 (\%) & $2.51^{\mathrm{a}}$ & $7.06^{\mathrm{b}}$ & $5.48^{\mathrm{c}}$ & 1.88 & $<0.0001$ \\
n-6 (\%) & $8.50^{\mathrm{a}}$ & $11.85^{\mathrm{b}}$ & $9.57^{\mathrm{ab}}$ & 2.19 & 0.0041 \\
n-6/n-3 & $3.39^{\mathrm{a}}$ & $1.68^{\mathrm{b}}$ & $1.74^{\mathrm{b}}$ & 1.51 & $<0.0001$ \\
P/S & $0.23^{\mathrm{a}}$ & $0.45^{\mathrm{b}}$ & $0.37^{\mathrm{c}}$ & 0.14 & $<0.0001$ \\
AI & $0.91^{\mathrm{a}}$ & $0.71^{\mathrm{b}}$ & $0.79^{\mathrm{b}}$ & 0.16 & $<0.0001$ \\
TI & $1.58^{\mathrm{a}}$ & $0.95^{\mathrm{b}}$ & $1.05^{\mathrm{b}}$ & 0.20 & $<0.0001$ \\
\hline
\end{tabular}

${ }^{1}$ Values with different superscript letters differ significantly, $\mathrm{P}<0.05$.

${ }^{2}$ Standard error of the means. 
vaccenic acid is more intensive in Sambucana lambs, and the high relative amounts of CLA and trans-vaccenic could be attributed to the milk in the diet of these lambs. The high percentage of CLA and transvaccenic acid in the pastured breeds is a clear advantage with respect to a healthy human diet. Numerous studies have demonstrated the beneficial effect of CLA on cardiovascular health, cancer and obesity (Benjamin et al., 2015). Emerging evidence also revealed that trans fats derived from milk and ruminant body fats, such as trans-vaccenic acid, have pronounced cytotoxic effect in some types of cancer or might suppress tumour growth (Blewett et al., 2009; Lim et al., 2014).

Significant differences in the PUFA amounts were also observed among breeds $(\mathrm{P}<0.0001)$. With regards to the proportion of total PUFA, the breeds could be ranked as Sambucana $>$ TMBC $>$ Biellese. In addition to the CLAs, the essential C18:2n-6 and C18:3n-3, significantly contributed to the highest PUFA amount in the meat of Sambucana lambs. While the differences in the proportion of C18:2n-6 were significant only between Sambucana and Biellese, the percentage of C18:3n-3 differed substantially among all three breeds, with highest values in Sambucana (3.00 \%) followed by TMBC (2.50 \%). The lowest proportion of C18:3n-3 was observed in Biellese (1.09\%). These discrepancies are not surprising and are due to the production systems. Generally, the ruminants reared under extensive conditions display higher levels of C18:3n-3, which is more abundant in grass than in grain feed (Aurousseau et al., 2007; Domínguez et al., 2015; Popova, 2014). On the other hand, the content of C18:3n-3 in the meat of Biellese lambs had also relatively high proportion, when compared to lambs reared in intensive conditions. This is also attributed to the pastures, despite the additional concentrate in the diet (Popova, 2014, 2007). Similarly, in a previous study that compares the effect of livestock production system in lamb meat quality, the authors observed higher C18:3n-3 content in animals reared in extensive than in semi-extensive system (Lorenzo et al., 2010). Results of other studies, however, do not confirm differences in the content of the essential fatty acids due to the rearing systems (Kaczor et al., 2010) or observe decreased amount of C18:3n-3 in semi-intensive systems vs. intensive systems (Borys et al., 2012).

The elevated amounts of C18:3n-3 quantified in meat from the extensively reared breeds beneficially affected the proportion of the long chain n-3 PUFA, in particular C20:5n-3 and C22:5n-3 (P < 0.0001). For these fatty acids, meat from Sambucana lambs showed the highest contents, while the lowest values were observed in the meat of Biellese lambs. The percentage of C22:6n-3 remained the lowest in Biellese $(0.34$ $\%)$ and the difference was significant when compared to Sambucana (0.49\%). The level of C22:6n-3 in TMBC was $0.44 \%$. The higher long chain n-3 PUFA content in meat from the extensively reared breeds in comparison to the Biellese $(\mathrm{P}<0.0001)$ shows that a significant amount of C18:3n-3 escapes biohydrogenation and is further desaturated and elongated to long chain derivatives. Significant differences among breeds was observed as well with regards to $n-6$ PUFA ( $P=0.0041$ ), being more pronounced between Sambucana (11.85\%) and Biellese ( $8.50 \%)$. The differences were due to the elevated content of C18:2n-6 and C20:4n-6 in the meat of Sambucana lambs. Despite the high percentage of total n-6 PUFA, the ratio n- $6 / n-3$ was favourably decreased in both Sambucana (1.68) and TMBC (1.74) when compared to Biellese (3.39) $(\mathrm{P}<0.05)$. In all three breeds $n-6 / n-3$ ratio is below the recommended value of 4.0 , which is considered beneficial for human health (Simopoulos, 2009). The discrepancies in the fatty acid profile were also reflected in the $\mathrm{P} / \mathrm{S}$ ratio, which was above the recommended minimum of 0.4 in the meat of Sambucana lambs, and in the lower AI and TI in the two breeds reared extensively. Atherogenic and thrombogenic indices take into account the different effects that single fatty acids might have on human health and, in particular, on the probability of increasing the incidence of pathogenic phenomena, such as atheroma and/or thrombus formation (Pilarczyk and Wójcik, 2015). In agreement with our results, beneficially decreased values of AI and TI were observed by Liotta et al. (2020) in m. Logissimus dorsi of lambs reared under extensive systems compared to semi-extensive. Other studies with lambs (Fiori et al., 2013;
Margetin et al., 2014; Margetín et al., 2018) also observed lower atherogenic or thrombogenic potential in meat of lambs reared on pasture.

\section{Conclusion}

The comparative analysis of the meat from the Biellese, Sambucana and TMBC lambs reared under semi-intensive and extensive production systems showed that, regardless of the rearing conditions, the three breeds render high quality meat with low fat content. Moreover, the fatty acids composition, and the atherogenic and thrombogenic indices of the meat showed significant differences and a clear advantage of the meat from the animals reared under extensive production system. Such variability indicates that rearing strategy can be used successfully to influence the lipid profile in a way that it can positively affect human health.

\section{CRediT authorship contribution statement}

Ursula Gonzales-Barron: Conceptualization, Formal analysis, Funding acquisition, Investigation, Methodology, Project administration, Resources, Software, Visualization, Writing - original draft, Writing - review \& editing. Teodora Popova: Software, Formal analysis, Writing - original draft, Writing - review \& editing. Roberto Bermúdez Piedra: Investigation, Methodology, Supervision, Validation, Visualization. Anna Tolsdorf: Investigation, Project administration, Validation, Visualization. Andreas Geß: Funding acquisition, Project administration, Supervision, Resources, Visualization, Validation, Writing - review \& editing. Jaime Pires: Project administration, Resources, Visualization, Writing - review \& editing. Rubén Domínguez: Investigation, Methodology, Supervision, Validation, Visualization. Francesco Chiesa: Investigation, Methodology, Supervision, Resources, Visualization. Alberto Brugiapaglia: Investigation, Methodology, Supervision, Resources, Visualization. Irene Viola: Investigation, Visualization. Luca M. Battaglini: Investigation, Methodology, Supervision, Resources, Project administration, Validation, Visualization. Mario Baratta: Funding acquisition, Investigation, Project administration, Resources, Supervision, Visualization, Writing - review \& editing. José M. Lorenzo: Conceptualization, Funding acquisition, Investigation, Methodology, Project administration, Resources, Supervision, Visualization, Writing - review \& editing. Vasco A.P. Cadavez: Conceptualization, Formal analysis, Funding acquisition, Investigation, Methodology, Project administration, Resources, Software, Visualization, Writing - original draft, Writing - review \& editing.

\section{Declaration of Competing Interest}

The authors declare that they have no known competing financial interests or personal relationships that could have appeared to influence the work reported in this paper.

\section{Acknowledgments}

The authors are grateful to EU ERA-NET programme and the Portuguese Foundation for Science and Technology (FCT) for funding the project "EcoLamb-Holistic Production to Reduce the Ecological Footprint of Meat (SusAn/0002/2016). CIMO authors are grateful to FCT and FEDER under Programme PT2020 for financial support to CIMO (UIDB/00690/2020). Dr. Gonzales-Barron acknowledges the national funding by FCT, P.I., through the Institutional Scientific Employment Programme contract. José M. Lorenzo is member of the HealthyMeat network, funded by CYTED (ref. 119RT0568). 


\section{References}

AOCS, 2005. AOCS official procedure Am5-04. Rapid determination of oil/fat utilizing high temperature solvent extraction. Sampling and Analysis of Vegetable Oil Source Materials. AOCS. American Oil Chemists Society, Urbana, IL, USA.

Atti, N., Mahouachi, M., 2009. Effects of feeding system and nitrogen source on lamb growth, meat characteristics and fatty acid composition. Meat Sci. 81, 344-348. https://doi.org/10.1016/j.meatsci.2008.08.011.

Aurousseau, B., Bauchart, D., Faure, X., Galot, A.L., Prache, S., Micol, D., Priolo, A., 2007. Indoor fattening of lambs raised on pasture. Part 1: Influence of stall finishing duration on lipid classes and fatty acids in the longissimus thoracis muscle. Meat Sci. 76, 241-252. https://doi.org/10.1016/j.meatsci.2006.11.005.

Barros, J.C., Munekata, P.E.S., de Carvalho, F.A.L., Pateiro, M., Barba, F.J., Domínguez, R., Trindade, M.A., Lorenzo, J.M., 2020. Use of tiger nut (Cyperus esculentus L.) oil emulsion as animal fat replacement in beef burgers. Foods 9, 44. https://doi.org/10.3390/foods9010044.

Battaglini, L.M., Tassone, S., Lussiana, C., Cugno, D., 2004. Sambucana sheep breeding in Valle Stura di Demonte and meat characteristics: present situation and outlooks on future. In: Dubeuf, J.-P. (Ed.), L'évolution des systèmes de production ovine et caprine: avenir des systèmes extensifs face aux changements de la société. Options Méditerranéennes Série A, 61, pp. 195-199.

Benjamin, S., Prakasan, P., Sreedharan, S., Wright, A.-D.G., Spener, F., 2015. Pros and cons of CLA consumption: an insight from clinical evidences. Nutr. Metab. (Lond) 12, 4. https://doi.org/10.1186/1743-7075-12-4.

Blasco, M., Campo, M.M., Balado, J., Sañudo, C., 2019. Effect of Texel crossbreeding on productive traits, carcass and meat quality of Segureña lambs. J. Sci. Food Agric. 99 3335-3342. https://doi.org/10.1002/jsfa.9549.

Blewett, H.J., Gerdung, C.A., Ruth, M.R., Proctor, S.D., Field, C.J., 2009. Vaccenic acid favourably alters immune function in obese JCR:LA-cp rats. Br. J. Nutr. 102, 526-536. https://doi.org/10.1017/S0007114509231722.

Bligh, E.G., Dyer, W.J., 1959. A rapid method of total lipid extraction and purification. Can. J. Biochem. Physiol. 37, 911-917. https://doi.org/10.1139/059-099.

Boles, J.A., Pegg, R., 1999. Meat Color. University of Saskatchewan, Saskatoon, Canada. Borys, B., Oprzadek, J., Borys, A., Przegalinska-Goraczkowska, M., 2012. Lipid profile of intramuscular fat in lamb meat. Anim. Sci. Pap. Reports 30, 45-56.

Boughalmi, A., Araba, A., 2016. Effect of feeding management from grass to concentrate feed on growth, carcass characteristics, meat quality and fatty acid profile of Timahdite lamb breed. Small Rumin. Res. 144, 158-163. https://doi.org/10.1016/j. smallrumres.2016.09.013.

Brugiapaglia, A., Lussiana, C., Franco, D., Lorenzo, J.M., Barrata, M., 2019. Health Implication of Biellese Lamb Meat Consumption, in: 65th International Congress of Meat Science and Technology. ICOMST, Berlin, Germany, p. 840.

Costa, R.G., Malveira Batista, A.S., de Azevedo, P.S., de Cássia Ramos do Egypto Queiroga, R., Madruga, M.S., de Araújo Filho, J.T., Batista, A.S.M., Azevedo, P.Sde, Queiroga, Rde C.Rdo E., Madruga, M.S., Filho, Araújo, de, J.T., 2009. Lipid profile of lamb meat from different genotypes submitted to diets with different energy levels. Rev. Bras. Zootec. 38, 532-538. https://doi.org/10.1590/s151635982009000300019 .

Cruz, B.C., Cerqueira, J., Araújo, J., Gonzales-Barron, U., Cadavez, V., 2019. Estudio de las características de crecimiento de corderos de las razas Churra Galega-Bragançana y Bordaleira-de-Entre-Douro-e-Minho. In: Alibés, M., Martínez, A., Jal, A., Lacosta, J., Górriz, M., Ascaso, S., Collado, D., Liesa, J., García, G. (Eds.), XVIII Jornadas Sobre Producción Animal, Producción Animal. AIDA, Zaragoza, Spain, pp. 66-68.

Devine, C.E., Graafhuis, A.E., Muir, P.D., Chrystall, B.B., 1993. The effect of growth rate and ultimate $\mathrm{pH}$ on meat quality of lambs. Meat Sci. 35, 63-77. https://doi.org/ 10.1016/0309-1740(93)90070-X.

Díaz, M.T., Álvarez, I., De La Fuente, J., Sañudo, C., Campo, M.M., Oliver, M.A., Font, I., Furnols, M., Montossi, F., San Julián, R., Nute, G.R., Cañeque, V., 2005. Fatty acid composition of meat from typical lamb production systems of Spain, United Kingdom, Germany and Uruguay. Meat Sci. 71, 256-263. https://doi.org/10.1016/j meatsci.2005.03.020.

Domínguez, R., Crecente, S., Borrajo, P., Agregán, R., Lorenzo, J.M., 2015. Effect of slaughter age on foal carcass traits and meat quality. Animal 9, 1713-1720. https:// doi.org/10.1017/s1751731115000671.

Domínguez, R., Barba, F.J., Centeno, J.A., Putnik, P., Alpas, H., Lorenzo, J.M., 2018a. Simple and rapid method for the simultaneous determination of cholesterol and retinol in meat using normal-phase HPLC technique. Food Anal. Methods 11, 319-326. https://doi.org/10.1007/s12161-017-1001-4.

Domínguez, R., Pateiro, M., Crecente, S., Ruiz, M., Sarriés, M.V., Lorenzo, J.M., 2018b. Effect of linseed supplementation and slaughter age on meat quality of grazing crossbred Galician x Burguete foals. J. Sci. Food Agric. 98, 266-273. https://doi.org/ 10.1002/jsfa.8466.

Ekiz, B., Demirel, G., Yilmaz, A., Ozcan, M., Yalcintan, H., Kocak, O., Altinel, A., 2013. Slaughter characteristics, carcass quality and fatty acid composition of lambs under four different production systems. Small Rumin. Res. 114, 26-34. https://doi.org/ 10.1016/j.smallrumres.2013.05.011.

Eurostat, 2019. Agriculture, Forestry and Fishery Statistics - 2019 Edition - Product Eurostat [WWW Document]. Eur. Comm. URL https://ec.europa.eu/eurostat/web /products-statistical-books/-/KS-FK-19-001 (accessed 5.10.20).

Fiori, M., Scintu, M.F., Sitzia, M., Addis, M., 2013. Dietary effects on meat chemical traits and fatty acidscomposition in intramuscular lipids of sarda $\mathrm{x}$ Ile de France heavy lambs. In: Ben Salem, H., López-Francos, A. (Eds.), Feeding and Management Strategies to Improve Livestock Productivity,Welfare and Product Quality Under Climate Change. Options Méditerranéennes: Série A, pp. 201-205. Zaragoza, Spain.
Fisher, A.V., Enser, M., Richardson, R.I., Wood, J.D., Nute, G.R., Kurt, E., Sinclair, L.A., Wilkinson, R.G., 2000. Fatty acid composition and eating quality of lamb types derived from four diverse breed $\times$ production systems. Meat Sci. 55, 141-147. https://doi.org/10.1016/S0309-1740(99)00136-9.

Franco, D., Rodríguez, E., Purriños, L., Crecente, S., Bermúdez, R., Lorenzo, J.M., 2011. Meat quality of "Galician Mountain" foals breed. Effect of sex, slaughter age and livestock production system. Meat Sci. 88, 292-298. https://doi.org/10.1016/j. meatsci.2011.01.004.

ISO 1442, 1997. International Standards Meat and Meat Products - Determination of Moisture Content. International Organization for Standarization, Geneva, Switzerland.

ISO 936, 1998. International Standards Meat and Meat Products - Determination of Ash Content. International Organization for Standarization, Geneva, Switzerland.

ISO 937, 1978. International Standardsmeat Andmeat Products - Determination of Nitrogen Content. International Organization for Standarization, Geneva, Switzerland.

Kaczor, U., Borys, B., Pustkowiak, H., 2010. Effect of intensive fattening of lambs with forages on the fatty acid profile of intramuscular and subcutaneous fat. Czech J. Anim. Sci. 55, 408-419.

Lim, J.-N., Oh, J.-J., Wang, T., Lee, J.-S., Kim, S.-H., Kim, Y.-J., Lee, H.-G., 2014. trans-11 18:1 Vaccenic Acid (TVA) Has a Direct Anti-Carcinogenic Effect on MCF-7 Human Mammary Adenocarcinoma Cells. Nutrients 6, 627-636. https://doi.org/10.3390/ nu6020627.

Liotta, L., Chiofalo, V., Lo Presti, V., Chiofalo, B., 2020. Effect of production system on growth performances and meat traits of suckling Messinese goat kids. Ital. J. Anim. Sci. 19, 245-252. https://doi.org/10.1080/1828051X.2020.1726832.

Lorenzo, J.M., Fuciños, C., Purriños, L., Franco, D., 2010. Intramuscular fatty acid composition of "Galician Mountain" foals breed. Effect of sex, slaughtered age and livestock production system. Meat Sci. 86, 825-831. https://doi.org/10.1016/j. meatsci.2010.07.004

Luciano, G., Biondi, L., Pagano, R.I., Scerra, M., Vasta, V., López-Andrés, P., Valenti, B., Lanza, M., Priolo, A., Avondo, M., 2012. The restriction of grazing duration does not compromise lamb meat colour and oxidative stability. Meat Sci. 92, 30-35. https:// doi.org/10.1016/j.meatsci.2012.03.017.

Margetin, M., Apolen, D., Oravcova, M., Vavrisinova, K., Peskovicova, m D., Luptakova, L., Krupova, Z., Bucko, O., Blasko, J., 2014. Fatty acids profile of intramuscular fat in light lambs traditionally and artificially reared / journal of central european agriculture, volume: 15, issue: 1 / JCEA. J. Cent. Eur. Agric. 15, 117-129.

Margetín, M., Oravcová, M., Margetínová, J., Kubinec, R., 2018. Fatty acids in intramuscular fat of Ile de France lambs in two different production systems. Arch. Anim. Breed. 61, 395-403. https://doi.org/10.5194/aab-61-395-2018.

Marino, R., Albenzio, M., Annicchiarico, G., Caroprese, M., Muscio, A., Santillo, A., Sevi, A., 2008. Influence of genotype and slaughtering age on meat from Altamurana and Trimeticcio lambs. Small Rumin. Res. 78, 144-151. https://doi.org/10.1016/j. smallrumres.2008.06.002.

Mendelsohn, R., 2003. The challenge of conserving indigenous domesticated animals. Ecol. Econ. 45, 501-510. https://doi.org/10.1016/S0921-8009(03)00100-9.

Mullen, A.M., Troy, D.J., 2005. Current and emerging technologies for the predictions of meat quality. In: Hocquette, J.F., Gigli, S. (Eds.), Indicators of Beef and Milk Quality. Wageningen Academic Publ, Wageningen, The Netherlands, pp. 179-190.

Pilarczyk, R., Wójcik, J., 2015. Fatty acids profile and health lipid indices in the longissimus lumborum muscle of different beef cattle breeds reared under intensive production systems. Acta Sci. Pol. Zootech. 14, 109-126.

Pompa-Roborzyński, M., Kedzior, W., 2006. Effects of crossbreeding and different feeding systems on slaughter value and meat quality of lambs reared in natural pastures of the Beskid Sądecki Mountains. Arch. Tierz., Dummerstorf 49, 268-274.

Popova, T., 2007. Effect of the rearing system on the fatty acid composition and oxidative stability of the M. longissimus lumborum and M. semimembranosus in lambs. Small Rumin. Res. 71, 150-157. https://doi.org/10.1016/j.smallrumres.2006.06.001.

Popova, T., 2014. Fatty acid composition of longissimus dorsi and semimembranosus muscles during storage in lambs reared indoors and on pasture. Emirates J. Food Agric. 26, 302-308. https://doi.org/10.9755/ejfa.v26i3.16771.

Priolo, A., Micol, D., Agabriel, J., 2001. Effects of grass feeding systems on ruminant meat colour and flavour. A review. Anim. Res. 50, 185-200. https://doi.org/ 10.1051/animres:2001125.

Salvatori, G., Pantaleo, L., Di Cesare, C., Maiorano, G., Filetti, F., Oriani, G., 2004. Fatty acid composition and cholesterol content of muscles as related to genotype and vitamin E treatment in crossbred lambs. Meat Sci. 67, 45-55. https://doi.org/ 10.1016/j.meatsci.2003.09.004.

Serra, A., Conte, G., Cappucci, A., Casarosa, L., Mele, M., 2014. Cholesterol and fatty acids oxidation in meat from three muscles of massese suckling lambs slaughtered at different weights. Ital. J. Anim. Sci. 13, 3275. https://doi.org/10.4081/ ijas.2014.3275

Simopoulos, A.P., 2009. Omega-6/omega-3 essential fatty acids: biological effects. World Rev. Nutr. Diet. 99, 1-16. https://doi.org/10.1159/000192755.

Song, M.K., Kennelly, J.J., 2003. Biosynthesis of conjugated linoleic acid and its incorporation into ruminant's products. Asian-Australasian J. Anim. Sci. 16, 306-314. https://doi.org/10.5713/ajas.2003.306.

Teixeira, A., Batista, S., Delfa, R., Cadavez, V., 2005. Lamb meat quality of two breeds with protected origin designation. Influence of breed, sex and live weight. Meat Sci. 71, 530-536. https://doi.org/10.1016/j.meatsci.2005.04.036. 
Tejeda, J.F., Peña, R.E., Andrés, A.I., 2008. Effect of live weight and sex on physicochemical and sensorial characteristics of Merino lamb meat. Meat Sci. 80, 1061-1067. https://doi.org/10.1016/j.meatsci.2008.04.026.
Ulbricht, T.L.V., Southgate, D.A.T., 1991. Coronary heart disease: seven dietary factors. Lancet 338, 985-992. https://doi.org/10.1016/0140-6736(91)91846-M.

Webb, E.C., Casey, N.H., Simela, L., 2005. Goat meat quality. Small Rumin. Res. 60, 153-166. https://doi.org/10.1016/j.smallrumres.2005.06.009. 